\title{
Transforming a Beauty Pageant: Mrs. America Contest in the Palisades Amusement Park and Asbury Park, NJ
}

\author{
Nogin Chung
}

\begin{abstract}
The paper examines the history and transformation of the Mrs. America Pageant that was first initiated as a part of the Palisades Amusement Park attractions and later moved to Asbury Park, NJ. It looks at how the idea of model motherhood was enacted in the contest for married women which had begun as a beauty contest emulating the Miss America Pageant. The contest which transformed itself into a "home-making Olympics" after the Second World War testing contestants' skills of cooking, baking, sewing, and even changing diapers in addition to judging their physical appearance truly reflected the social ideal for American women in the Cold War period. The paper assesses how the contest helped to consolidate the notion of the perfect housewife, implying that beauty and home economics went together, and contributed to the professionalization of women's work at home.
\end{abstract}

Beauty pageants have been the very targets of the Second Wave feminists since the 1970s as a typified example that symbolizes troubling male gaze. Carrying on a gendered notion that a woman's body is an object of visual pleasure, the pageants have been criticized for quantifying and measuring various women's bodies under highly racialized criteria. ${ }^{1}$ The pageants were and still are the perpetuation of appearance-based rewards and celebration of conventional and troubling norms of heterosexual femininity. Beginning in the first decades of the twentieth century, however, the Westernized beauty contest prototype of individuated competition has proliferated in communities and nations across the globe. Such popularity results from the very flexibility of beauty pageants, which can be molded to fit an array of differing historical and cultural contexts and agendas. As idealized women's bodies in art have often served to personify and embody national values and virtues as well as abstract concepts such as beauty, love, literature, art, and war, beauty queens have performed as icons of their locality and community. They have functioned as representative faces of their originated groups. Their apolitical bodies have become symbolic fixtures of socio-political categories like ethnicity, race, and nation. Recent historians note that beauty contests have been significant sites for constructing notions of ethnic identities as seen in African American, Native American, Japanese American, and Chinese American beauty pageants despite their adoption of racialized aesthetics and argue how national identities have been molded through those events in non-Western countries. ${ }^{2}$ Their studies show that pageants are inherently political and often reinforce hegemonic social relations.

One particular beauty pageant that answered political needs of the postwar period was the Mrs. America pageant. It bolstered a distinct type of American women which was being promoted by the government and various industries. With the end of the Second World War, many Rosie the Riveters had to give up their jobs to marry G.I. Joes who were returning home from the battle fronts and became housewives. Historian Elaine Tyler May claims that mainstream American

\footnotetext{
${ }^{1}$ For more information on the relation between feminism and beauty pageants, see Bonnie Dow, "Feminism, Miss America, and Media Mythology," Rhetoric and Public Affairs 6, no. 1 (2003): 127-149.

${ }^{2}$ For more information on those pageants, see Natasha Barnes, "Face of the Nation: Race, Nationalisms, and Identities in Jamaican Beauty Pageants," Massachusetts Review 35 (Autumn 1994): 471-92; Wendy Kozol, "Miss Indian America: Regulatory Gazes and the Politics of Affiliation," Feminist Studies 31, no. 1 (2005): 64-94; Judy Tzu-Chun Wu, "Loveliest Daughter of Our Ancient Cathay! Representations of Ethnic and Gender Identity in the Miss Chinatown USA Beauty Pageant," Journal of Social History 31, no. 1 (1997): 5-31.
} 
rhetoric drastically changed in the late 1940s, focusing on women's reproductive function and domestic duties, parting from its previous argument for women's productive contributions to the war effort. ${ }^{3}$ Entering a new era of cold war politics, American popular culture portrayed its domesticated women in high heels and Dior dress as an epitome of American-ness as opposed to Soviet's overall-clad working women. Images of American housewives became a symbol of American prosperity and its supposedly superior capitalist system. The Mrs. America pageant was aptly formulated reflecting the culture's need for an actual persona to play the quintessential American hou sewife while offering a new outlet for married women to enter into the public realm through presentations of their bodies and later their professionalized skills in household tasks. This paper examines the early history of the Mrs. America pageant and how it was initiated as a beauty contest and later transformed into a professionalized contest on the "good old-fashioned wifely arts" as well as on pulchritude. ${ }^{4}$ While it thrived on the social norms of white supremacy, middle-class confinement, and heterosexual desire, the Mrs. America pageant offered something new.

The Mrs. America pageant had its beginning as a part of the Palisade Amusement Park attractions in 1938. Bert Nevins, one of the top publicists of the day, was hired by the owners of the park to ensure enough press, which led him to mastermind a beauty contest for married women as a "publicity stunt" for the park as he later told the New Yorker. ${ }^{5}$ The park was located in Fort Lee on the New Jersey Palisades overlooking the Hudson River just across from midtown Manhattan. It began as a trolley park in 1898 and developed into a popular amusement park. When Irving and Jack Rosenthal brothers bought the park in 1935, however, it was losing $\$ 80,000$ a year. The Rosenthals worked hard to turn the park into a profitable enterprise. Their newly hired Bert Nevins had previously handled public relations for Coney Island's Luna Park and had been in charge of the New Jersey State Fair publicity and advertising. ${ }^{6}$ Thus he knew what was needed and should be done for promoting an amusement park.

A publicity stunt Nevins organized was a beauty contest for married women. His motive was to prolong tourist traffic beyond Labor Day. It was the very same as that of the Miss America pageant which had been founded in 1921 as an attempt to extend the tourism season beyond Labor Day in Atlantic City, a popular summer beach resort. The Miss America pageant was the very first national beauty contest and became the largest, the most prestigious, competitive, and well-known pageant in the United States. ${ }^{7}$ While Palisades Park did not have a beach as Atlantic City did, its convenient location for Manhattan and New Jersey dwellers meant it could pull in large crowds with good attractions. Still, another beauty contest for single girls in New Jersey

\footnotetext{
${ }^{3}$ Elaine Tyler May, "Rosie the Riveter Gets Married," in The War in American Culture, ed. Erenberg and Hirsch (Chicago: University of Chicago Press, 1996), 128-43. 29.

4 "Mrs. America," Asbury Park Evening Press, November 9, 1950.

5 "Mrs. America." New Yorker (September 30, 1950), 19.

${ }^{6}$ Vince Gargiulo, Palisades Amusement Park: A Century of Fond Memories (New Brunswick: Rutgers University Press, 1995), 50; News and Notes of the Advertising World, New York Times, July 19, 1937.

${ }^{7}$ Frank Deford, There She Is: The Life and Times of Miss America (New York: The Viking Press, 1971), 110-116; Kimberly A. Hamlin, "Bathing Suits and Backlash: The First Miss America Pageants, 1921-1927," in There She Is, Miss America: the Politics of Sex, Beauty, and Race in America's Most Famous Pageant, eds. Elwood Watson and Darcy Martin (New York: Palgrave Macmillan, 2004), 29.
} 
would probably not draw much interest since the Miss America contest had been established quite a reputation already- despite a few years of discontinuation in the 1920s and 1930s. ${ }^{8}$

The Miss America committee unwittingly offered a good opening for Bert Nevins in 1938. It was the first year that the committee set a stricter rule. Now the contestants for the Miss America pageant had to be between the ages of eighteen and twenty-eight, and never married, divorced, or had a marriage annulled. When the Miss America contest eliminated any possibility of married women participating, Nevins got an idea for his park. Why should married women be barred from the pageant? What about a pageant for married women only? He had just been married and realized that married women had the same aspiration for admiration as single women did. He even invited his wife, Marion, to be the first entrant (though she declined the offer). ${ }^{9}$ His idea was that anyone could be a crowned beauty, including married women. The contest was an immediate success, bringing a huge crowd and their enthusiastic responses. ${ }^{10}$ The contest was mainly about a bathing suit parade, which provided a good attraction for the park.

When Bert Nevins launched the Mrs. America pageant in 1938, he was initially emulating the Miss America pageant. Mrs. America was selected for her beauty alone. The only requirement to compete in the contest was a marriage license. Most entrants in the first year's competition were former models, show girls and dancing instructors. The winner was Mrs. Margaret Chamberlain, a model. She had modeled for department stores like Bloomingdale's in Ohio and won a beauty pageant at a Cleveland fair before she entered the Mrs. America pageant. ${ }^{11}$ A publicity photograph taken after she won the title proves that the contest was searching for a wedded version of Miss America. Chamberlain is shown here in a bathing suit and high heels with her "Mrs. America" sash. Without her sash, she could be mistaken for a winner of the national beauty contest for single girls, since her poise is almost identical to that of the 1938 Miss America, Marilyn Meseke, who was also from Ohio. ${ }^{12}$ Both of them show confidence in their appearance; Chamberlain highlights her waistline by putting her hands around it and Meseke assumes a classical contrapposto pose. They are bathing beauties with "perfect proportions, movie-star looks and scanty costume." 13 Miss America was not required to exhibit talent at that time, and neither was Mrs. America. Nobody knew or cared whether Mrs. America "could fry an egg or wash out a pair of socks." ${ }^{14}$ Mrs. America was really not much different from Miss America.

It was only after the war that the contest reshaped itself to select the perfect housewife rather than the reigning beauty who happened to be married. The experience of the Second World War instigated the transformation of the contest. Wartime conditions caused widespread changes in American life, and Mrs. America was not an exception. Perfect bodily proportions were not enough to satisfy the needs of the United States at war. She had to support the war effort on

\footnotetext{
8 “25 Years of Miss America,” Life (September 1946), 59.

9 "Bert Nevins, 56, Press Agent, Dies," New York Times, July 20, 1966.

${ }^{10}$ See an original video footage from Mrs. America, Sound and Visual Collection, Minnesota Historical Society, St. Paul.

${ }^{11}$ Amy L. Edwards, "Margaret Chamberlain Turned Modeling into 1938 Beauty Title,” Orlando Sentinel, July 19, 2002.

12 “25 Years of Miss America," Life (September 1946), 61.

13 “What Happened to Mrs. America's Bathing Suit?” Woman's Home Companion (January 1957), 10.

${ }^{14}$ Ibid.
} 
home front. On the one hand, she temporarily took over "men's jobs" exemplified by Rosie the Riveter. On the other hand, she was asked to prudently run her family, as seen in a 1942 propaganda poster by U.S. Department of Agriculture, entitled "Mrs. America buys food with care." It shows how a Mrs. America exhibits wise consumer behavior during the war in the form of comic strips where she studies, reads, makes notes, and then shops. Through planning what to buy in advance, comparing prices, and checking her purchase before use, she performs her duty as homemaker in a professional manner. At the bottom of the image, the phrase, "Wise buying helps win the war" reveals the purpose of such a careful spending pattern: patriotism. ${ }^{15}$

Realizing what had been asked of American women during the war, Nevins must have felt his pageant for the postwar period should be different. His first action was to set up Mrs. America, Inc. in 1945 and he became its president. It was an effort to make the contest a nationwide event, independent from Palisades Amusement Park. Until 1945, the contest was held at a local level, despite its grandiose name, and most entrants were from sections of New Jersey, Connecticut, upper New York State, Pennsylvania, and Delaware.

Because of the 1944 fire at the Palisades, the contest was not held that year and Mrs. America, Inc. began to search for a new place to host the pageant and new sponsors who would support the event financially. Nevins wanted to expand his contest beyond a local venue. First, he made a deal with Lever Brothers, an important manufacturer of domestic cleaning products in 1945. The deal required the newly selected Mrs. America of 1945 be on tour to appear at fashion shows as part of their department-store promotion for Lux. ${ }^{16}$ The deal lasted only for a year as Lever Brothers dropped their fashion shows in the next year. Nevins persisted to find a tie with a "Mississippi cotton concern." 17 This new connection led to the 1946 coronation of Mrs. America in an unlikely place for a beauty pageant: a football field just before the University of Mississippi-Mississippi State football game.

Despite some difficulties in the first three years after break-up with Palisades Park, Nevins eventually found a location that could host the contest in $1948 .{ }^{18}$ It was Asbury Park in New Jersey, which had been looking for a post-Labor Day attraction along the lines of the Miss America pageant in Atlantic City. With a new permanent location, the real change was happening. In addition to having the mayor of Asbury Park the pageant's honorary chair man to strengthen the bond with the city, Nevins made extra efforts to promote the contest nationwide. First, he invited celebrities to act as judges in the contest. Among the best known stars invited were model expert Harry Conover and his wife Candy Jones, artist Russell Patterson, comedian Jack Pearl of Baron Munchausen radio fame, singer Vic Damone, and Paula Lawrence, Broadway stage star. ${ }^{19}$ Next was television. The winner of the contest was scheduled to be on air, for an interview with "We the People" radio and television shows. ${ }^{20}$ The final stages of the

\footnotetext{
15 “Mrs. America buys food with care," One-sheet poster, 1942, Poster Collection, Minnesota Historical Society, St. Paul.

16 “Mrs. America.” New Yorker (September 30, 1950), 19.

17 Ibid.; "Crowned 'Mrs. America,"” New York Times, November 24, 1946.

${ }^{18}$ The contest was not held in 1944 and 1947. Mrs. America Pageant Booklet, 1958, 38. Minnesota Historical Society Library Collection, St. Paul.

19 "Stage, Radio Stars to Judge Mrs. America Contest Here," Asbury Park Evening Press, September 1, 1948; "Fair Will Star Mrs. America," Asbury Park Evening Press, September 5, 1948.

20 “Mrs. America To Be on Air," Asbury Park Evening Press, September 8, 1948.
} 
contest were even televised and the 1949 contest, more significantly, by the American Broadcasting Company network for two days. ${ }^{21}$ With the change of its location and growing media coverage, the pageant sought to differentiate itself from its counterpart in Atlantic Cityto be more than a beauty contest. The pageant was promoted as a search for the "best looking and best homemaker among America's married women."22

The final winner would be selected "on the basis of her ability as a hou sewife and homemaker, as well as her personal charm." This new requirement of dexterity in domestic tasks in order to be Mrs. America paralleled the normative definition of American hou sewife in the postwar period. When married women became homebound after the end of war as G.I.s were returning home, their role as housewives became professionalized. Based on their war experience as Rosie the Riveter and wise patriotic consumer, they were now armed with professional minds that geared towards home management. The Mrs. America contest provided a new ground to show off their professionalism by turning its attention to the domestic world of cooking and cleaning from its previous focus exclusively on physical beauty. Nevins even declared in 1950: "It's not a beauty contest." 23

Indeed, when the Mrs. America contest final was staged on the boardwalk in Asbury Park before the thousands of spectators, with the crowning of the winner in Convention Hall, the event was divided into two parts: beauty and domestic attributes. ${ }^{24}$ The judges were also divided into two groups: celebrities who determined the winner on her pulchritude and home economics specialists who examined each contestant's ability in homemaking chores. ${ }^{25}$ In order to highlight the domestic side of Mrs. America, it was announced that the winner would officially open the New Jersey State fair at Trenton and make daily appearance in the domestic arts building, presenting some of her recipes. ${ }^{26}$ Mrs. America was to match the prize winning jams and preserves.

The method to determine contestants' knowledge on domestic work was rather trivial in the beginning. The 1948 contestants had to submit their macaroni recipes to the judges before the contest. During the contest, they had to display one item they had sewed or knitted themselves and then answer one "home-making quiz." ${ }^{27}$ The question was on macaroni. ${ }^{28}$ That was all. Following were evening gown and bathing suit parades. They were the highlights of the event. As a photograph of all the Mrs. America finalists in bathing suits that decorated the front page of a local newspaper indicates, the climax of the pageant remained to be a bathing suit gala. Presenting candidates for America's perfect housewife still required a moment of sexual

\footnotetext{
21 "Rivals Arrive in City Today," Asbury Park Evening Press, September 10, 1948; "ABC-TV to Cover Judging of 'Mrs. America' Contest in Asbury Park Sept. 10-11," New York Times, August 12, 1949. The Miss America Pageant was first broadcasted in 1954. For more information, see Deford, 193.

22 "Mrs. America Title Winner to Receive \$5,000 in Prizes," Asbury Park Evening Press, September 11, 1948.

23 "Mrs. America." New Yorker (September 30, 1950), 19.

24 "Mrs. America Contest," New York Times, September 12, 1948.

${ }^{25}$ Among the judges of the contestants' domestic ability included Helen Larzelere, head of the domestic department of the New Jersey State Fair and Howard Fox, fashion stylist for I. J. Fox. "Stage, Radio Stars to Judge Mrs. America Contest Here," Asbury Park Evening Press, September 1, 1948.

26 "Fair Will Star Mrs. America," Asbury Park Evening Press, September 5, 1948; "Mrs. America To Be On Air," Asbury Park Evening Press, September 8, 1948.

27 "Rivals Arrive In City Today," Asbury Park Evening Press, September 10, 1948.

28 “Mrs. America To Be Chosen In City Today," Asbury Park Evening Press, September 12, 1948.
} 
titillation. In fact, the winner of the 1948 contest was a "shapely, 21 -year old, blonde Philadelphia model, who was married only two and a half months ago." 29 It was proven that her five years of modeling experience with training at the Barbizon Modeling School in New York benefited more to win the title than years of married life.

This was soon to be changed for the criteria for home-making abilities were strengthened each year. In 1949, the final judging was expanded to involve quizzes on bed-making, diapering, sewing, cooking and a number of other housewifely chores as well as doughnut recipes. ${ }^{30}$ For the 1950 contest, the finalists had to give a public demonstration of their cooking ability for the first time, in addition to sweeping floors and displaying samples of their crocheting. ${ }^{31}$ They were required to actually cook some articles of food at eight ranges in varied colors installed on the stage. ${ }^{32}$ That year, the winner of the cooking session was named Mrs. America, indicating that now cooking became a crucial factor than beauty. ${ }^{33}$ The next year, the rule was finalized that judging should be based 50 percent on homemaking ability and 50 percent on beauty. ${ }^{34}$ It became official that only a competent homemaker can be crowned Mrs. America. When Mrs. Penny Duncan won the title that year, her bread and cheese casserole recipe might well be regarded as a "token of her home-making ability." ${ }^{35}$ In 1952, contenders for the title were asked to do more than cooking. They were required to demonstrate their ability to sew, peel apples, polish floors, cook and even "put diapers on baby-size dolls." "36 The idea was that perfect housewives should be more than good cooks. They should be good at all sorts of household chores.

The Mrs. America contest's effort to exalt housework was, on the other hand, tied with commercial interests. Nevins actively cultivated profitable relationships with manufacturing companies. He ran advertising series to get sponsors and was also seeking any events or venues where its winner could appear personally as a publicity stunt including home shows, supermarkets, state fairs, and trade expositions. ${ }^{37}$ It hired a press agent just to supervise such business connections. He was appointed director of merchandising for the new "Mrs. America" supermarket merchandising plan in order to coordinate "tie-ups between grocery product manufacturers and supermarkets throughout the country." 38 The relationship with certain manufacturers developed into something more than endorsements and appearances. It literally determined the contents of the contest since categories and awards were created for the sponsors. The sewing contest was sponsored by the Singer Sewing Machine, the yeast-raised baking event by Gas Appliance Manufacturers Association, and the Music Education and Appreciation Essay

\footnotetext{
29 "Blonde Philadelphia Bride Wins Mrs. America Title Before 3,000," Asbury Park Evening Press, September 13, 1948.

30 “Mrs. America Judging Starts Here Tonight,” Asbury Park Evening Press, September 10, 1949.

31 “Johnstown Matron Made 'Mrs.' America,” New York Times, September 11, 1950.

32 "Finalists Parade Today in Mrs. America Event," Asbury Park Evening Press, September 9, 1950.

${ }^{33}$ Ibid.

34 "Homemaker Ability Counts Half at Mrs. America Event," Asbury Park Evening Press, September 8, 1951; "Mrs. America To Be Chosen This Afternoon," Asbury Park Evening Press, September 9, 1951.

35 “"Mrs. America' Is Chosen," New York Times, September 10, 1951.

36 "Mrs. America Chosen," New York Times, September 8, 1952.

${ }^{37}$ Advertisement for Mrs. America, Inc. New York Times, September 9, 1948; Advertisement for Mrs. America, Inc. New York Times, September 13, 1948; Advertisement for Mrs. America, Inc. New York Times, September 2, 1952; Advertisement for Mrs. America, Inc. New York Times, September 3, 1952.

${ }^{38}$ Advertising and Marketing, New York Times, June 25, 1953.
} 
by Thomas Organ. ${ }^{39}$ Those who won in these categories along with the final winner would be awarded a product made by its sponsor.

The activities of the winner were also commercially motivated. She could profit from her titleshe would get modeling fees when Nevins lined up endorsements for her-and she also would get fees for personal appearances. For example, the 1949 winner probably made between $\$ 12,000$ and $\$ 15,000$ from touring state fairs and homemaking shows and modeling. The advertising contracts the winners received were often with the sponsors of the contest and products for the home such as Tappan Gas Range, Fleischmann's Active Dry Yeast, and Aunt Jemima. The advertisements often featured photographs of the winner with her adorable children, expressing happiness and contentment. The selling point was not her personal attractiveness or sexual charm but rather her expertise as a homemaker.

Mrs. America perpetuated the ideal of womanhood and family values. Since her ability as a housewife and homemaker was proved to be the best in the nation, her relationship with her husband may well be just as perfect. However it was not always the case. Janice Pollock, original winner of the $1947 \mathrm{Mrs}$. America title, had to decline a six-month tour of the country as part of her reward because of her husband's disapproval. This 24-year-old mother of four had no choice but to go back home weeping openly. Due to media attention and whole controversy over the reality of unhappy marriage of the winner, the pageant committee decided not to go with Pollock, for her conflict tainted the image of how Mrs. America should lead her domestic life. The runner-up from South Carolina was crowned queen of the country's married women before a football crowd in Mississippi. ${ }^{40}$ The whole incident shows that the smile on Janice Pollock's face in a publicity photo with her husband and their four young children at home could be read as a fabricated ideal image, not a genuine one. After the incident, the contest required all the contestants and their husbands to sign an agreement that could prevent similar disputes. ${ }^{41}$

The transformation of the Mrs. America pageant from a bathing-beauty show into serious home economics tournament provides a showcase of how the postwar period imposed certain normative ideals of womanhood on married women. When the judges of the Mrs. America Contest were no longer looking for a woman of perfect physical proportions, they were not abandoning the concept of the ideal woman. They were including more requisites to be one. When the pageant moved to Ellinor Village in Florida in 1954, never returning back to the Garden State, its selection process became more complicated. For thirteen days, each contestant was given a small bungalow where she could stay with her family; she was asked to perform more than a dozen commonplace hou sehold tasks daily in the assigned bungalow and judged following the "Olympic point scoring system." 42 The pageant became more of Olympic games in homemaking and targets of its thorough inspections included not only contestants' home management skills but also their life styles and families. Its underlying premise was that a crowned winner should provide happiness to her husband and children through dexterous

\footnotetext{
39 "Trophies and Awards for Various Events at the National Finals," Mrs. America Pageant (Fort Lauderdale, Florida: Mrs. America, Inc., 1958), 30.

40 "Crowned 'Mrs. America,"” New York Times, November 24, 1946.

41 "Mrs. America, Inc.," Mrs. Minnesota Betty Bach file, Sound and Visual Collection, Minnesota Historical Society, St. Paul.

42 "How the Judging is Done," Mrs. America Pageant (Fort Lauderdale, Florida: Mrs. America, Inc., 1958$), 11$.
} 
performance in her domestic duties. Its focus on home economics was largely driven by the postwar era's advocacy of family values and Bert Nevins who gradually allowed a more prominent presence of contestants' husbands and children in the pageant and made the event highly family-friendly. With Nevins's retirement and growing feminist voices, however, the pageant had its last stage in 1969, only to be revived as a simple beauty pageant in 1977 .

The Mrs. America contest's early history illustrates the central contradiction of the pageant. It objectified women but also celebrated their agency to perform household duties. It espoused professionalism of housewives but sexualized their bodies since its bathing suit parade remained to be the climax. And it advocated the significance of domesticity but provided these women excitement of the public realm--although it was a limited one. 